Volume 13

\title{
In Defense of Peace: Aron Trainin's Contributions to International Jurisprudence
}

Thomas Earl Porter

North Carolina Agricultural \& Technical State University

Follow this and additional works at: https://digitalcommons.usf.edu/gsp

\section{Recommended Citation}

Porter, Thomas Earl (2019) "In Defense of Peace: Aron Trainin's Contributions to International Jurisprudence," Genocide Studies and Prevention: An International Journal: Vol. 13: Iss. 1: 98-112. DOI:

https://doi.org/10.5038/1911-9933.13.1.1588

Available at: https://digitalcommons.usf.edu/gsp/vol13/iss1/11

This Articles is brought to you for free and open access by the Open Access Journals at Digital Commons @ University of South Florida. It has been accepted for inclusion in Genocide Studies and Prevention: An International Journal by an authorized editor of Digital Commons @ University of South Florida. For more information, please contact digitalcommons@usf.edu. 
In Defense of Peace: Aron Trainin's Contributions to International Jurisprudence

Acknowledgements 


\title{
In Defense of Peace: Aron Trainin's Contributions to International Jurisprudence
}

\author{
Thomas Earl Porter \\ North Carolina Agricultural \& Technical State University \\ Greensboro, North Carolina, USA
}

The Soviet Union played a major role in the establishment of the International Military Tribunal (IMT) by resolutely promoting the idea of an international trial of Nazi Germany's leaders for the criminal actions perpetrated by its forces upon both civilians and prisoners of war during its invasion and occupation of the Soviet Union during the Second World War. Moreover, only a handful of Western scholars have noted that the Soviets were also early proponents of the use of the legal principle of conspiracy (the term used by Soviet jurists was "complicity," this "new" legal concept was used in Stalin's infamous "show trials" but had no place in continental European jurisprudence) and had also played an instrumental role in contributing to the precept that held aggressive war in and of itself could be legally construed as a criminal act. ${ }^{1}$ While many historians are familiar with Andrei Vyshinskii from his role as chief prosecutor of Stalin's Moscow trials in the late 1930s, in his capacity as head of the Institute of State and Law of the Russian Academy of Sciences Vyshinskii came to rely on the expertise of one Aron Naumovich Trainin.

Trainin was one of the founders of Soviet criminal justice law and was well known in international legal circles not only from his voluminous legal writings (many of which were translated) but also from his participation in international conferences. Along with Vyshinskii, he was responsible for elucidating the Soviet concept of international law (which, as Trotsky opined, would not even have been necessary if the worldwide proletariat had but recognized the historical task set before it). His contributions would include not only the idea of "crimes against peace" which would be incorporated into the Charter of the International Military Tribunal (IMT) at Nuremberg, thus "becoming a part of the recognized body of contemporary international law," but also the use of the theory of complicity to try the Nazi leadership for yet another innovative twist, the formulation of the principle of the criminality of "aggressive war." ${ }^{2}$ Vyshinskii supported Trainin in his intellectual pursuits and that Stalin trusted him as well can be seen in the fact that Trainin was one of but two Soviet signatories of the London Conference charter in 1945 and then served as legal advisor to the Soviet prosecution team at Nuremberg. Despite working for these malevolent individuals, his Western colleagues respected and admired him, considering him "a distinguished legal academician" who was "an agreeable man to do business with." 3

Aron Naumovich Trainin was born into a working- class family in Vitebsk on July 9, 1883. At age 10 he left home and enrolled in school in Kaluga where by the age of 12 he was supporting himself by giving lessons. He graduated first in his class (as evidenced by his receiving the gold medal) and in 1903 matriculated at Moscow State's Juridical School. ${ }^{4}$ As a member of the prerevolutionary students' movement he was thrice arrested by the tsarist regime but these youthful indiscretions evidently did not prevent him from graduating on time in 1908 upon the somewhat puzzling acceptance of his thesis entitled "The Class Struggle and Punishment in the History of Russian Law." ${ }^{5}$ He was immediately seconded to the University's Department of Criminal Law in preparation for a career as an academic where he set to work writing several basic textbooks on criminal law, criminology, and the criminal justice system. According to his biographical sketches, however, he abruptly left in 1911 when the reactionary Kasso became Minister of Education. Along with many other scholars he sought employment at the Shaniavskii People's University where he

\footnotetext{
${ }^{1}$ Notable exceptions include Francine Hirsch's excellent article "The Soviets at Nuremberg: International Law, Propaganda, and the Making of the Postwar Order," American Historical Review 113, no. 3 (2008), 701-730 and George Ginsburgs, Moscow's Road to Nuremberg: The Soviet Background to the Trial (The Hague: Martinus Nijhoff, 1996).

2 Ginsburgs, Moscow's Road, 26.

${ }^{3}$ Hirsch, The Soviets at Nuremberg, 713.

${ }^{4}$ G. I. Bogush, "A.N. Trainin i znachenie ego idei dlia niurnbergskogo protsessa," in Niurnbergskii protsess: uroki istorii, eds. N.S. Lebedeva and V.V. Ishchenko (Moscow: Institut vseobshchei istorii RAN, 2007), 167. ${ }^{5}$ Ibid.
}

Thomas Earl Porter. "In Defense of Peace: Aron Trainin's Contributions to International Jurisprudence" Genocide Studies and Prevention 13, 1 (2019): 98-112. @2019 Genocide Studies and Prevention. 
taught until after the October Revolution. ${ }^{6}$ Returning to Moscow State he resumed his research and teaching duties and by 1921 was accorded the rank of professor. Ultimately, he would become a member of the prestigious USSR Academy of Sciences in 1946.

Trainin spent much of his early scholarly career writing academic textbooks as well as legal treatises that would lay the foundations for Soviet criminal law. Included among these works was Obshchee uchenie o sostave prestupleniia (A General Theory of the Structure of Criminality), Khoziaistvennye prestupleniia (Economic Crime) and most important of all from the Soviet stand point, Uchenie o souchastii (The Theory of Complicity). But his biographer notes that at the end of the 1920s and beginning of the 1930s his scholarly attention "turned toward a completely new, little known and extraordinary sphere of interest - toward international criminal law."7 In his first major work Ugolovnaia interventsiia (Criminal intervention) Trainin analyzed the "numerous resolutions of the League of Nations" as well as the proceedings of its "symposia, conferences and commissions which examined questions concerning the codification of international criminal law." Although, as his most recent Russian biographer (2007) admits, as opposed to his biographer during the late Soviet period (1969), Trainin's work had significant "ideological baggage" (for example, much of the work was devoted to a critique of "bourgeois intervention against the USSR" during the Civil War), Trainin's treatise was the first time in Russian literature that "research was begun into the recognition of responsibility for international crimes." Trainin forcefully "advanced the idea of individual responsibility for international crimes...the realization of which was established during the course of the Nuremberg deliberations." ${ }^{8}$ The Soviet leadership would use this novel concept to call for the prosecution of the Nazi leadership for conspiracy to commit aggressive war.

Of course, the concept of aggressive war itself was not entirely novel as the General Treaty for the Renunciation of War (also known as the Kellogg-Briand Pact) which was signed by 15 nations (including Weimar Germany) on August 27, 1928 and registered as part of the League of Nations Treaty Series a week later, explicitly called for the renunciation of war between the contracting parties as a solution to any kind of conflict. Article II of the treaty stated that "the settlement or solution of all disputes or conflicts of whatever nature or of whatever origin they may be...shall never be sought except by pacific means." ${ }^{\prime 9}$ Eventually, another 40 nations (including the Soviet Union just two days later, on August 29) indicated their intention to subscribe to the treaty's provisions. The Soviet Union also concluded supplemental treaties with Latvia, Estonia, Poland and Romania (the so-called Litvinov Protocols) on February 9, 1929 which reiterated the Pact's provisions and were signed separately since that treaty had not yet been ratified by enough states to come into legal force. The Soviet Union never formally signed the Pact but its entrance into the League of Nations in 1934 legally required the USSR's assent to all Treaties that had been adopted by that body.

The Soviet Union also signed a series of non-aggression pacts with its neighbors in the 1930s (including, of course, the notorious Molotov-Ribbentrop Pact) which made the Soviet Union a leading advocate for the diplomatic principle of collective security. In addition, as Francine Hirsch has observed, Trainin had in 1937 published his The Defense of Peace and Criminal Law in which he castigated the League of Nations for failing to make aggressive war a criminal offense and not providing for any sort of international court to punish aggressors. Most notable in this regard was the fact that Andrei Vyshinskii, Stalin's procurator general, wrote an introduction to the book in which he asserted that "criminal law must be utilized for defending peace, must be mobilized against war and against the instigators of war."10

\footnotetext{
${ }^{6}$ R.A. Rudenko, A.N. Trainin Izbrannye Proizvedeneniia (Moscow: Gosizdat, 1969), 6. The Shaniavskii People's University was established in 1908 by a retired general turned philanthropist who envisioned free university education for all regardless of nationality, class or gender. It ultimately was transformed into the well- known CPSU Higher School but after the collapse of the USSR became the Russian State University for the Humanities.

${ }^{7}$ Bogush, A.N. Trainin, 168.

${ }^{8}$ Ibid.

${ }_{9}^{9}$ Michael R. Marrus, The Nuremberg War Crimes Trial, 1945-46: A Documentary History (Boston and New York: St. Martin's Press, 1997), 15.

${ }^{10}$ Quoted in Ibid., 706.
} 
For Soviet jurists this principle was supposedly enshrined in "The Decree on Peace," which was promulgated in 1917 when, "under the leadership of the Communist Party headed by the great leader V. I. Lenin the tsarist regime was overthrown....and the revolutionary people of Russia adopted the decree...leading the entire world into a new era of international relations." ${ }^{11}$ The obvious Soviet verbiage aside, as is well known the decree called for a peace "without annexations or indemnities." By "annexations" the Bolsheviks meant the "seizure by force and violence" of weak and small nations by the larger and more powerful. Aggressive war was thus to be considered a "crime against humanity" and Soviet assessments of Trainin's works always linked his more than 200 scholarly treatises over the course of his stellar academic career to his consistent effort "to convert this national foreign policy law into the code of international law." One biographer has gone so far as to assert, "law, in the service of peace, was the leitmotiv of the many works of A. N. Trainin, and as such was the motive wellspring of his social activity." 12

With the first of his four wartime notes on November 25, 1941, People's Commissar for Foreign Affairs Molotov began the Soviet campaign to try the Nazi leadership for complicity in criminal activity. Molotov described the reprehensible treatment of Soviet prisoners of war and laid "all responsibility for these inhuman actions of the German military and civil authorities on the criminal Hitlerite government."13 For their part the Germans asserted that they were not bound to adhere to such strictures since the Soviet Union had not been a signatory to international agreements such as The Hague Conventions of 1899 and 1907, and especially the Geneva Convention in 1929. This was immaterial since, unlike the Kellogg-Briand Pact that called for no force to be used between signatories in a dispute, the Geneva Convention's stipulations relative to the treatment of POW's were binding upon any state that acceded to the agreement so long as the opposing side accepts and applies the provisions. In point of fact, the Soviets insisted that they had de facto agreed to adhere to the rules governing the conduct of military forces vis-à-vis prisoners of war. In Molotov's note of April 27, 1942, by which time the scope and enormity of Nazi crimes against Soviet prisoners was all too apparent, with over two million of them dead, he wrote

...Being true to the principles of humanity and respect for its international obligations, the Soviet government even in present circumstances does not intend to resort to reprisals against German war prisoners, and continues to abide by the undertakings as regards the regime of war prisoners, which the Soviet Union assumed under The Hague Conventions of 1907 , which was signed, but is now treacherously violated in all its provisions, by Germany. ${ }^{14}$

Of course, the Soviet government had also completely disregarded these international laws concerning the treatment of POW's during its campaigns against Finland and Poland in 1939 and 1940. And it has been irrefutably established and acknowledged by the Russian government that the Soviets executed over 25,000 Polish officers in the spring of $1940 .{ }^{15}$ But the Soviet government's public pronouncements consistently demanded that the entire Nazi leadership be held accountable for war crimes committed by its forces. The Kremlin insisted that "severe punishment must

\footnotetext{
${ }^{11}$ Rudenko, A.N. Trainin, 8.

${ }^{12}$ Ibid., 50.

${ }^{13}$ Soviet Government Statements on Nazi Atrocities (London: His Majesty's Lithographic Office, 1946), 7-10.

${ }^{14}$ Ibid., 50 and Nota Narodnogo Komissara Inostrannykh Del Tov. V. M. Molotova O Chudovishchnykh Zlodeianiiakh Zverstvakh i Nasiliiakh Germanskikh Vlastei v Okkypirovannykh Sovetskikh Raionakh i ob Otvetstvennosti Germanskikh Vlastei Za Eti Prestupleniia (People's Commissar of Foreign Affairs Comrade V. M. Molotov's Note Concerning the Monstrous Deeds, Atrocities and Acts of Violence of the German State in the Occupied Soviet Regions and About the Responsibility of the German State For These Crimes), April 27, 1942, (USHMM, RG-22.009.01.06), 13. Records Group (RG) 22.009 contains Soviet Ministry of Foreign Affairs archival records from the Molotov Secretariat which document early Soviet knowledge of the Holocaust and interaction with the Allies about a joint policy declaration, materials relating to the creation of the Extraordinary State Commission to Investigate German-Fascist Crimes Committed on Soviet Territory and miscellaneous reports of the SovInformBuro including articles prepared for the Soviet press. It also holds archival materials from the Central State Archive of the Ministry of Defense (TsGAMO) located in Podolsk which document atrocities perpetrated by the Nazis as does RG.04.050.

${ }^{15}$ R.G. Pikhoia and V. P. Kozlov, eds., Katyn (Moscow: ROSSPEN, 1997).
} 
overtake all who are guilty of these most atrocious crimes against culture and humanity, all the Hitlerite criminals without exception - from the lance-corporal in the army to the lance-corporal on the throne."16

The atrocities perpetrated by German forces upon the prisoners of war and the civilian population were seen by the Soviets as part of a criminal conspiracy to pursue a deliberate war of annihilation. In his second wartime note of January 6, 1942, Molotov delineated the "wholesale robbery, despoliation of population and monstrous atrocities" committed by the Germans in the Soviet Union and noted that "the inhuman regime which has been established by the GermanFascist authorities for prisoners of war has become the lot of the civilian population." ${ }^{17}$ Molotov once again took pains to emphasize the criminal conspiracy that was at the heart of Nazi policies in the Soviet Union

Irrefutable facts prove that the regime of plunder and bloody terror against the noncombatant population of occupied towns and villages constitutes not merely the excesses of individual German officers and soldiers, but a definite system previously planned and encouraged by the German Government and the German High Command... ${ }^{18}$

These efforts were undertaken despite the fact the legal principle of a conspiracy to commit a criminal offense had no place in continental European law. Francine Hirsch notes that "the Soviets were keen proponents of this charge from early on, recognizing its great utility." ${ }^{19}$ Most accounts do indeed wholly attribute the use of the conspiracy charge to American ingenuity and their persistence in overcoming the other Allies' objections. Although the idea that political responsibility for waging a war of conquest resided with the aggressor state had been first adumbrated by the Kellogg-Briand Pact and, as Kristen Sellers has noted, had been advocated by legal scholars other than Trainin, ${ }^{20}$ his argument that criminal responsibility for such actions must necessarily lie with the state's politicians was indeed unique.

According to Trainin, Hitler and his minions were guilty of "organizing and perpetrating the most heinous crime in the history of the human race, the perfidious attack on the Soviet Union accompanied by the flagrant violation of all human standards and all the canons and regulations of international law." ${ }^{21}$ And in fact the Soviets began to lay the foundation for such a tribunal with the trial of three German prisoners of war in the city of Kharkov in December 1943. In his August 1943 article "The Responsibility for Nazi Crimes," which was then broadcast (in English) two months prior to the meeting of the allies' foreign ministers in Moscow (and then reprinted in Soviet Monitor, again, in English, and distributed to government agencies abroad by Soviet embassies) Trainin had reiterated his arguments on conspiracy and the criminal responsibility of the German political and business leadership.

The Kharkov trial featured three accused war criminals who confessed to atrocious crimes but more important was the statement made by one of them that the principal war criminals were Hitler, Himmler and Rosenberg. ${ }^{22}$ In addition, Trainin would later point to these proceedings and draw two more important conclusions. Although the Soviets were insisting that prisoners of war be treated in accordance with The Hague convention of 1907, Trainin was concerned lest war criminals use their status as prisoners to avoid their just punishment by being classified as both "bandit and as military personnel." But in perhaps his most important observation he said that these criminals might well try to find "legal" methods to evade responsibility by claiming they were acting under orders. One defendant in the Kharkov trial had made just such an argument

\footnotetext{
${ }^{16}$ Aron N. Trainin, Ugolovnaia otvetsvennost' gitlerovtsev, ed. A. Ia. Vyshinskii (Moscow: Iurid. Izdatel'stvo NKIU Soiuza SSR, 1944), 87.

${ }^{17}$ Statements, 16.

${ }^{18}$ Quoted in Ginsburgs, Moscow's Road, 33.

${ }^{19}$ Hirsch, Soviets at Nuremberg, 707.

${ }^{20}$ Kristen Sellers, "Crimes Against Peace" and International Law (Cambridge, UK: Cambridge University Press, 2013$), 50$.

${ }^{21}$ Ibid., 51.

${ }^{22}$ The Spectator, December 23, 1943, 1.
} 
by saying he had simply been following the orders of his superiors. Trainin noted the defendants "were tried for the misdeeds they themselves committed, with their own hands, for the crimes they committed personally. And for these crimes a command is not a defense." ${ }^{23}$ The "orders are orders" defense eventually used at Nuremberg would, of course, be inadmissible.

Trainin's second major work "Ob ugolovnoi otsvetsvennosti gitlerovtsev" (On the Criminal Responsibility of the Hitlerites, published in 1944) which had also been almost immediately translated into English ${ }^{24}$ had reiterated the argument that "peace is the greatest social value" and that war itself should be a punishable criminal act. Ginsburgs, called it "a pioneering attempt to gain recognition for the phenomenon of crimes against peace..." ${ }^{25}$ Since Soviet jurisprudence embraced the idea of conspiracy Trainin now put forward that legal principle as well by devoting a chapter to the concept of complicity, defining it as "a complex phenomenon" that "embraces various understandings among criminals" and can include "the dangerous form of participation in an organization..." Members of such organizations may not know each other "but should answer for all of their criminal activities." ${ }^{26}$ Molotov thus continued to put forward the Soviet demand for a war crimes trial using the conspiracy principle. He argued that "in reporting all these atrocities committed by the German invaders to all governments with which the USSR has diplomatic agreements the Soviet government lays all the responsibility for these inhuman and rapacious acts committed by the German troops on the criminal Hitlerite government of Germany." ${ }^{27}$ The principle that the entire political and military chain of command was just as guilty as the actual perpetrators in the field for any and all violations of the norms of war was already on its way to being established.

The Soviet Government had already collected countless battle reports, orders and other documents that clearly proved that the Nazis" "bloody atrocities had been undertaken in accordance with the carefully compiled and elaborate plans of the German government and German High Command." On April 27, 1942, ten months after Hitler's invasion of the Soviet Union, Molotov had sent his third wartime note, a single-spaced, twenty-six page note to "all embassies and ambassadors with which the USSR has diplomatic relations." The missive, "Concerning the Monstrous Crimes, Atrocities, and Acts of Violence of the German State in the Occupied Soviet Regions and the Responsibility of the German State for these Crimes" was a virtual indictment of the Nazi regime's conduct in the Soviet Union. In this extremely detailed explication of the atrocities committed by German forces Molotov noted that these transgressions were not random but instead were calculated and "not manifested as the episodic excesses of undisciplined military units." ${ }^{28}$ This diplomatic note broke down the Nazis' heinous transgressions in Russia into a halfdozen categories, including the methodical plunder of the country's population, the destruction of cities and villages, the enslavement of her people and deportation of several million more to Germany for forced labor, the veritable extermination of the Soviet population and prisoners of war and the liquidation of Russian national culture and the cultures of other peoples of the USSR.

Molotov took pains to point out that the evidence presented "not only supports the assertions of the Soviet government of the planned nature of these evildoings as outlined in the notes of November 25, 1941 and January 6, 1942," but also "shows that the Hitlerite government and its accomplices have reached the limits of cruelty and moral depravity in its bloody criminal attack on the freedom, welfare, culture and very life of the Soviet peoples." 29 The document went into explicit details of the myriad atrocities and crimes of German forces in Russia and connected the perpetration of those crimes with the military orders that had been captured, including several from Hitler and Goering. The grisly specifics of some of the many massacres of men, women

\footnotetext{
${ }^{23}$ Quoted in Arieh J. Kochavi, Prelude to Nuremberg: Allied War Crimes and the Question of Punishment (Chapel Hill: University of North Carolina Press, 2005), 69.

${ }^{24}$ Sellers, Crimes Against Peace, 49.

${ }^{25}$ Ginsburgs, Moscow's Road, 78-79.

${ }^{26}$ Quoted in Hirsch, Soviets at Nuremberg, 707.

${ }^{27}$ Quoted in Ginsburgs, Moscow's Road, 33-34.

${ }^{28}$ Nota, USHMM, RG-22.009.01.06, 1.

${ }^{29}$ Ibid., 2.
} 
and children were presented, as well as detailed retellings of the numerous summary executions of citizens and the horrific treatment of Soviet prisoners. The wanton burning and looting of villages and destruction of equipment, buildings and entire cities was chronicled and the looting of property was also carefully catalogued. The idea that all these acts were not only criminal but committed as part of a plan determined by the highest civil and military authorities would become a key part of the Nuremberg trial. Molotov promised in conclusion that "Hitler's government and its accomplices will not escape severe responsibility and deserved punishment for all their unparalleled crimes perpetrated against the peoples of the USSR and against all freedom loving peoples." 30

Thus, the idea that the Nazi war effort was essentially a criminal undertaking and Germany's leading political and military figures ought to be brought before the bar of justice was being advanced forcefully by the Soviets by early 1942. In September of that year, in a speech in the House of Commons, Winston Churchill seemingly supported the Soviet position when he pledged the support of Great Britain in ensuring that "those who are guilty of the Nazi crimes will have to stand up before tribunals in every land where their atrocities have been committed in order that an indelible warning may be given to future ages..." and Franklin Roosevelt declared that it would be United States policy "that the successful close of the war shall include provision for the surrender to the United Nations of war criminals. It was the Soviet government, however, that insisted upon an international tribunal, considering it

Essential to hand over without delay for trial before a special international tribunal, and to punish according to all severity of criminal law, any of the leaders of Fascist Germany who in the course of the war have fallen into the hands of states fighting against Hitlerite Germany. ${ }^{31}$

By 1942, the Soviets were already preparing for the day of reckoning with the Nazis leadership. In July 1942, a draft proposal by G. Aleksandrov, head of the Propaganda and Agitation section of the Central Committee of the Communist Party was circulated that called for the establishment of an "Extraordinary State Commission for the investigation of atrocities, violence and other crimes committed by the German army on the regions of Soviet territory temporarily occupied and an account of the damage inflicted by the German-Fascist forces on the population of the USSR and to the Soviet state." ${ }^{32}$ Aleksandrov asserted that the "violence, mass murders, destruction of priceless material and cultural treasures of the Soviet people, and establishment of the forced labor regime..." were the result of "a systematic plan which had earlier been devised and authorized by the German government and the German High Command." 33 Therefore, the "Soviet people demand retribution for the crimes of the German Fascist forces..." and to that end it "was necessary to conduct an exact inventory of all the evil crimes of the Hitlerite army on the territory of the USSR, the violation of the norms of international law, of the rules and customs of the conduct of war..." 34

Aleksandrov, however, also noted the ad hoc nature of efforts to compile evidence for future use in war crimes trials. He wrote that "a series of organizations had taken it upon themselves to undertake such an inventory as well as the collection of materials concerning the crimes of the German army." Such activities were "undertaken without a unified plan" and "organized poorly" therefore it was "necessary to provide for the formation of an Extraordinary State Commission which would be engaged in the investigation and inventory of crimes, atrocities, violence, and thievery of the German Fascist army and an accounting of this army's material damage to the Soviet state and to Soviet citizens." The commission would need to be invested with "special authority for the collection of all necessary materials..." and would be responsible to the Sovnarkom

\footnotetext{
${ }^{30}$ Ibid., 13.

${ }^{31}$ Ibid., 54.

${ }^{32}$ USHMM, RG 22.009.01.07, 12.

${ }^{33}$ Ibid.

${ }^{34}$ Ibid.
} 
(Council of People's Commissars, the Soviet government's cabinet). ${ }^{35}$ On October 28, Aleksandrov forwarded to Molotov a draft decree from the Presidium of the Supreme Soviet concerning the establishment of an "Extraordinary State Committee (sic) for the inventory of the German-Fascist invaders' evildoings." ${ }^{36}$ Molotov made extensive corrections on the proposal (including the name of the commission) and added that the principal purpose of the commission would be to oversee "the unification and conformity of the inventory already being conducted by Soviet state organs of the crimes and damage inflicted by the invaders..." ${ }^{37}$

In addition to a full accounting of the damages inflicted upon the USSR, the commission would also be charged with "establishing, in all cases where circumstances permitted, the identity of the German-Fascist criminals, the guilty in organizations which have committed evildoings on occupied Soviet territory, with the goal of bringing these criminals to justice and to their most severe punishment." ${ }^{38}$ Thus, on the basis of the October 1942 declaration the Soviets in November set up an "Extraordinary State Commission for ascertaining and investigating crimes perpetrated by the German-Fascist invaders and their accomplices, and the damage inflicted by them on citizens, collective farms, social organizations, State enterprises and institutions of the USSR." Announced in Pravda as a decree of the Presidium of the Supreme Soviet and as a resolution from the Council of People's Commissars, this body was charged with compiling the evidentiary materials for a future war crimes trial. A policy paper submitted to the commission by a Soviet jurist in February 1943, entitled "Organization of criminal prosecution for crimes connected with the war" called for the trial of Hitler and his minions on conspiracy charges before an international court in order to lay bare the evils of Nazism; the commission's charter was formally approved in March 1943. ${ }^{39}$ The Western Allies, of course, were not nearly as far along since as we have seen they had not yet definitively agreed to the idea of a post-war international war crimes tribunal but had merely agreed that the German's conduct of the war had in fact been criminal and that individuals could be tried at the scene of their crimes by the responsible authorities.

On April 3, 1943, a staff of 116 people with a budget of 2,669,000 rubles was approved ${ }^{40}$ Nikolai Shvernik was appointed as head of the commission. Other notables included Andrei Zhdanov (both he and Shvernik were also members of the Politburo), Andrei Vyshinksii, Trofim Lysenko, the writer Aleksei Tolstoi, and Semyen Budennyi. A secretariat was established to coordinate the gathering and collation of the evidentiary materials to be used in future war crimes trials; P.I. Bogoiavlenskii was appointed as its executive secretary. The secretariat included departments charged with recording the evidence of atrocities against Soviet citizens, damage to state and collective farms, damage to industry, transportation and communications, damage to cooperatives, trade unions and other civic organizations, damage to cultural, scientific and medical institutions, churches, etc., and finally a department to collect the evidence of damage to Soviet citizens. Much like the party and state apparatus, sub commissions were established at the republic and regional levels. Members always included the first secretary of the Central Committee of the Communist Party at each level (Nikita Khrushchev was head of the Ukrainian SSR's, commission), as well as the chair or deputy chair of the Council of People's commissars and representatives from the local political police. ${ }^{41}$

Care was taken to ensure the participation in the commission's work of a representative cross section of Soviet officials and citizens, and in fact more than 7 million people supposedly took part in the process. ${ }^{42}$ Instructions were adopted by the Commission on May 31, 1943, which required the staff of the Commission to travel around the recently liberated areas of the Soviet Union

\footnotetext{
${ }^{35}$ Ibid., 14.

${ }^{36}$ Ibid., 17.

${ }^{37}$ Ibid., 19.

${ }^{38}$ Ibid.

${ }^{39}$ N.S. Lebedeva, Podgotokva Niurnbergskogo protsessa (Moscow: Izdatel'stvo nauka, 1975), 26-30.

${ }^{40}$ Ginsburgs, Moscow's Road, 38.

${ }^{41}$ Ibid., 38-39; USHMM, RG 22.009.01.07, 25-31.

${ }^{42}$ Ginsburgs, Moscow's Road, 38.
} 
and empower local committees to investigate Nazi crimes and atrocities. The statute required that these investigations be completed within one month of the area's liberation. Dossiers were meticulously compiled listing the details of Nazi crimes, the units and persons that had committed them, accomplices, etc. along with forensic reports, statements by local citizens and captured German documents. The Commission ultimately collected more than a quarter million statements and estimated the damage to the regions surveyed at almost 700 billion rubles. Members of the commission reopened graves, exhumed bodies, and interrogated German prisoners of war. These prisoners

went through a screening which divided officers from men, separated party and army SS troops, and Gestapo members from non-party men, and singled out individuals held accountable for specific atrocities, on the basis of evidence compiled by the ubiquitous War Crimes Commission, which had branches in every army division and every local soviet. ${ }^{43}$

In those areas that had seen enormous devastation, and where the local organs of government had not yet been reconstituted, special Red Army military intelligence units composed of officers and medical doctors investigated the crimes and drew up the protocols (akty), or findings of fact, which were then forwarded to the Main Political Administration of the Workers and Peasants Red Army (GLAVPURKKA) and from there sent on to the Extraordinary Commission. ${ }^{44}$ These particular documents have not yet been studied and offer interesting contrasts with the records filed by the civilian local and regional commissions. My research into these documents indicates that the military committees faithfully recorded the eyewitness testimony of the locals and were extremely diligent in revealing the human cost of the war (as compared with the protocols of the Extraordinary Commission which seemingly were more attentive to material damage, perhaps with an eye toward future reparations). Of special interest is the fact that many of these Red Army officers were Jewish, especially the medical staff.

Both the civil and military commissions took down the testimonies of the eyewitnesses at the scene of the crimes and atrocities. In those reports where the victims were Jews, the term was at first written down as these eyewitnesses clearly indicated that Jews had been the principal victims. Yitzhak Arad has shown that these testimonies were then often changed and the word Jews replaced with "Soviet citizens." At the next level in many of the civilian akty the word Jew was found less frequently, and finally in the reports from the republic committee's the word was almost never to be found. The fact that some reports were indeed edited can be seen through a simple comparison of the initial reports by Red Army committees with those ultimately forwarded to Moscow by the union republic committees. For example, one of the earliest protocols documenting Nazi atrocities was submitted by a "flying" military committee to GLAVPURKKA in January 1942 by senior political instructor (politruk, or politicheskii rukovoditel') Kriuchkin, political instructor Fadeikin, and medical officer Gurvich which recorded the eyewitness testimony of several persons from the village of Alfer'evo, Volokolamsk district, Moscow region. In it the villagers recounted how "upon arrival in November 1941, the German soldiers and officers rounded up without exception all the Jews...they held them for hours in the cold after having taken from them all their warm clothing. Most of these people were women, old men and children. They shot these unfortunates and out of 100 persons 80 were killed and 20 were wounded. The Germans forbade the rendering of any kind of medical assistance to the wounded and the other 20 froze to death." 45 Other atrocities were also recounted in detail including the rape and "cruel treatment of our women and girls." The corresponding report forwarded by the regional committee to Moscow in 1944 repeated this

\footnotetext{
${ }^{43}$ Edgar Snow, The Pattern of Soviet Power (New York: Random House, 1945), note 18, 97.

${ }^{44}$ There were three to five of these committees assigned to each Red Army "front." There were several dozen of these "fronts" and although they were usually identified with a geographic region ( $1^{\text {st }}$ Baltic Front, $2^{\text {nd }}$ Ukrainian front, Caucasus Front, etc.) they were in fact military formations unique to the Russian and Soviet military; composed of three to five armies and they should not be confused with the Western usage of the term which denotes a broad geographic area of military operations.

${ }^{45}$ USHMM, RG 22.008M, 72-73.
} 
information verbatim but simply read that "100 peaceful Soviet citizens" had been murdered. ${ }^{46}$ Interestingly, in all his writings about the victims of Nazi outrages Trainin, who was himself Jewish, often mentioned Jews and not once did he elect to employ the politically acceptable term of "peaceful Soviet citizens."

Given the scope of these crimes as well as Churchill's speech in Parliament and Roosevelt's oft repeated expressions of moral outrage Stalin undoubtedly assumed that the Allies were on the same page insofar as the idea of convening a post-war international war crimes trial was concerned. But that was manifestly not the case. As Howard Ball has noted, as late as 1945, the Western Allies were largely agreed on a plan to summarily execute Nazi war criminals and tried to convince the Soviet Union to go along. ${ }^{47}$ Most scholars are aware of US Secretary of the Treasury Henry Morgenthau's proposal drawn up in late 1944 essentially to turn Germany into a veritable potato farm after the war. ${ }^{48}$ Less well known, however, was the provision to distribute a list of 2,500 Nazi war criminals (including political and military leaders, police officials, industrialists, etc.) to the advancing Allied troops so that they could be summarily executed upon capture.

Winston Churchill had in fact agreed with this idea. Churchill would later claim that Stalin's remark at the Tehran conference that fifty thousand of Hitler's henchmen ought to be "rounded up and shot at the end of the war" was in fact indicative of Stalin's "serious intent." Considering the historical record clearly shows otherwise I would submit that Stalin was merely poking fun at the Prime Minister for his reluctance to endorse the idea of an international war crimes trial. Even ruthless dictators can have a sense of humor. Writing Roosevelt just a week before Hitler's suicide and two weeks before Germany's formal unconditional surrender, Churchill reiterated his unease with the Americans' conversion to the Soviet idea of an international war crimes trial

[His Majesty's Government is] deeply impressed with the dangers and difficulties of this course [judicial proceedings], and they think that execution without trial is the preferable course (italics mine). [A trial] would be exceedingly long and elaborate, [many of the Nazis deeds] are not war crimes in the ordinary sense, nor is it at all clear that they can properly be described as crimes under international law. ${ }^{49}$

Stalin's determination for an international war crimes trial can be seen in the talking points ultimately agreed upon at the Moscow Conference in 1943. It was reported that

The Russians... insisted on a declaration concerning the punishment of those individuals responsible for German atrocities... [and] contended that the category of such war criminals embraced everyone from the Nazi higher-ups...down to the meanest Wehrmacht private...in the gruesome fulfillment of directives. ${ }^{50}$

The joint resolution issued by the Allies at the behest of the Soviet Government had only agreed that major political and military figures whose crimes had "no particular localization" would be "punished by the joint decision of the Governments of the Allies." Of course, this vague formulation was merely a sop to the Soviets who were still insisting on an international war crimes trial. It was, however, agreed that "petty associates" would be "brought back to the scene of their crimes and judged on the spot by the peoples they have outraged" and further pledged to "pursue them to the uttermost ends of the earth and...deliver them to their accusers in order that justice

\footnotetext{
${ }^{46}$ Soobshchenia Chrezvychainoi Gosudarstvennoi Kommissii po Ustanovleniiu i Rasledovaniiu Zlodeianii Nemetsko-Fashistikh Okkupantov i ikh posobnikov na Vremenno Okkupirovannoi Territorii SSSR, Moscow, 1944, tom 27, 864.

${ }^{47}$ Howard Ball, “The Path to Nuremberg: 1941-1945," in The Genocide Studies Reader, ed. Samuel Totten (New York and London: Routledge, 2009), 427.

${ }^{48}$ Bradley Smith, The American Road to Nuremberg: The Documentary Record, 1944-1945 (Stanford: Stanford University Press, 1982), 28-29.

${ }^{49}$ Quoted in Ibid.

${ }^{50}$ Quoted in Ginsburgs, Moscow's Road, 48.
} 
be done." 51 The Soviets, however, continued to demonstrate their commitment to an international tribunal; just a week after the Moscow Conference Stalin said

...Together with our Allies, we must adopt measures to ensure that all the Fascist criminals responsible for the present war and the sufferings of the people should bear stern punishment and retribution for all the crimes perpetrated by them no matter in what country they may hide. $^{52}$

U.S. Secretary of War Henry Stimson had disagreed with Morgenthau's plan and had also believed all along that an international judicial proceeding was required.$^{53}$ It was his Department that devised the outlines of the criminal indictment that ultimately would be utilized at Nuremberg. The plan charged the Nazi regime with a criminal conspiracy to wage aggressive war and commit crimes against humanity

The whole movement had been a deliberate, concerted effort to arm for war, forcibly seize the lands of other nations, steal their wealth, enslave and exploit their populations, and exterminate the...Jews of Europe. ${ }^{54}$

But as we have seen, these ideas had already been put forward by the Soviets in Trainin's books published in 1937 and 1944. Francine Hirsch has made the persuasive argument that it was in fact these books, and especially the second that was translated immediately into English, French and German, that proved instrumental in preparing the groundwork for the legal justification for the charges leveled at Nazi leaders at the IMT. Using archival materials she showed how the book was discussed in October 1944, at a meeting of the United Nations War Crimes Commission and ultimately was reviewed by officials in both the State and War Departments of the United States. One of those officials was a War Department lawyer named Murray Bernays. It would be he who ultimately drew up the American plan to charge the German leadership with criminal conspiracy. Bernays even cited Trainin's definition of a "crime against peace" in his memo to the White House. Robert Jackson, who would act as the United States' chief prosecutor at Nuremberg, also agreed with Trainin's argument. ${ }^{55}$ Trainin's definition would essentially form the basis for the charges of "war crimes" and "crimes against humanity" lodged against the Nazi leadership at Nuremberg. And his definition of "complicity" was replicated in the conspiracy charge in the Nuremberg Charter that agreed that "leaders, organizers, instigators, and accomplices participating in the formulation or execution of a common plan or conspiracy to commit" war crimes "are responsible for all acts performed by any persons in execution of such plan." 56

Most histories credit the United States with the major legal innovations of the Nuremberg Trials; however, Hirsch rightly concludes that the Soviets played a major role in formulating the legal rationales for crimes against peace and complicity. Moreover, they insistently called for an international trial to bring the Nazi criminals to justice. This in face of the fact that Roosevelt and Churchill had met in Quebec in September 1944, and agreed with a proposal put forward by Lord Simon that called for the execution of Nazi war criminals. The Anglo-American duo further agreed "to put to Marshal Stalin Lord Simon's proposal for dealing with the major war criminals, and to concert with him a list of names." ${ }^{\prime 57}$ Roosevelt had not seriously entertained the idea of a post war trial and extra-judicial executions in keeping with Lord Simon's and Morgenthau's plans remained

\footnotetext{
${ }^{51}$ Quoted in Ibid., 49.

${ }^{52}$ Josef Stalin, War Speeches, Orders of the Day and Answers to Foreign Press Correspondents During the Great Patriotic War (London, n.d.), 82.

${ }^{53}$ Foreign Relations of the United States: The Conference at Quebec, 1944 (Washington, DC: Government Printing Office, 1972), 123-125.

${ }^{54}$ Quoted in Joseph Persico, Nuremberg: Infamy on Trial (New York: Viking, 1994), 17.

${ }^{55}$ Ibid., 708.

${ }^{56}$ Ibid., 709

${ }^{57}$ Quoted in Telford Taylor, The Anatomy of the Nuremberg Trials (New York: Alfred A. Knopf, 1992), 31.
} 
the official policy until early 1945 when, after the massacre of captured American soldiers at Malmedy in Belgium on December 17, 1944, an enraged public demanded justice. The massacre of 70 American soldiers had finally galvanized public and official opinion as to the criminality of the Nazis. Although undoubtedly sympathetic to the reports of the millions upon millions of murdered Jews, Soviet prisoners of war and civilians that had taken place so far away, it was this event that led to the demand for the punishment of those responsible for such atrocities.

Even U.S. Attorney General Francis Biddle, who had opined that there should not be any prosecution of prewar acts or acts against German nationals and that the War Department's idea of charging Nazi political and military leaders with conspiracy should be dropped, now wrote that Malmedy was just part of a "purposeful and systematic conspiracy to achieve domination of other peoples by deliberate violations of the rules of war as they have been accepted and adhered to by the nations of the world. ${ }^{\prime 58}$ The fact that the massacre was perpetrated by the Waffen SS also led Biddle to agree with the plan (finally drawn up by Murray Bernays) to charge the German leadership with criminal conspiracy. He later wrote that it "was the shooting of American officers and soldiers after their surrender at Malmedy by an SS regiment, acting under orders..." that convinced him. Stimson and Secretary of State Cordell Hull seized on this opportunity to argue

While [executive action....arrest and execution] has the advantage of a sure and swift disposition, it would be violative of the most fundamental principles of justice, common to all the United Nations. This would encourage the Germans to turn these criminals into martyrs and in any event, only a few individuals could be reached in this way. Consequently, [although there are serious legal difficulties involved in a judicial proceeding], we think that the just and effective solution lies in the use of the judicial method...[which] will, in addition, make available for all mankind to study in future years an authentic record of Nazi crimes and criminality. ${ }^{59}$

Roosevelt finally agreed and brought up the idea of an international war crimes trial with Churchill and Stalin at the Yalta Conference in February 1945. As we have seen, Stalin, whose nation had of course seen the worst of the Nazi atrocities, had been calling for precisely such a trial for several years now. But Churchill continued to insist on the summary execution of top Nazis through to the beginning of April 1945. It was only after the liberation of the Nazi concentration camps and extermination centers that the British grudgingly assented to the idea. Even then, as late as the summer of 1945 (this after Churchill's departure from office and the London Conference had already convened in June to determine the procedures for the International Military Tribunal), the British asserted it would be far easier and save everybody time by simply shooting the defendants.

After hostilities were concluded the Americans were often able to dictate the particulars of the post war judicial proceedings, such as the trial being held in Nuremberg instead of Berlin as the Soviets wished; in part this was because they had the major Nazi war criminals in their custody. ${ }^{60}$ But it should be kept in mind that it was the Red Army that liberated the extermination camps of Auschwitz, Treblinka, Sobibor, Belzec, Chelmno and Majdanek. The photographs and films of the concentration camps in Germany itself were as close as most Americans or Britons came to the industrial murder carried out by the Nazis and, of course, they had not witnessed the wholesale industrial slaughter of millions of human beings in the East. Much of the documentation and evidence needed to convict the Nazi criminals would necessarily have to come from the Soviet investigations. The GPU "flying" military intelligence committees continued their work as the Red Army crossed Poland and entered Germany.

After Hitler's suicide, the United Nations Conference on International Organization met in San Francisco on April 25, 1945, to establish a successor to the discredited League of Nations. Representatives of the Soviet Union, United States, Great Britain and France discussed a draft of a

\footnotetext{
${ }^{58}$ Quoted in Smith, The Documentary Record, 117.

${ }^{59}$ Quoted in Richard Minear, Victor's Justice: The Tokyo War Crimes Trial (Princeton: Princeton University Press, 1971), 9-10.

${ }^{60}$ Though the opening session of the International Military Tribunal was in fact first convened at Soviet insistence in Berlin before being moved to Nuremberg.
} 
proposal by the United States that an International Military Tribunal be convened to try Nazi war criminals. The following basic principles were agreed upon:

First, trial of major war criminals rather than political disposition; second, return of criminals whose crimes had fixed geographical localization to the countries where their crimes were committed; third, an international military tribunal to hear the cases of the major war criminals...

The Four Powers then met in London in June of 1945 to hammer out the framework for this process. The representatives agreed that the Nazi political and military leadership were to be charged not only with war crimes, crimes against humanity, and the violation of the rules of warfare, but also for launching a war of aggression.

Interestingly, both the Soviets and Americans argued that the treaties and conventions that had existed prior to the Second World War clearly showed that the world's peoples had recognized aggressive war as being an international crime and that, unlike the new concept of genocide, the sanctions that might be levied against individuals for their participation in this crime would not be "ex post facto." But while the Americans wanted to move forward and define "aggression," the Soviets insisted that this was a task for the United Nations and Great Britain and France agreed with this position. Many general histories credit the United States with being in the forefront of the campaign to bring Nazi war criminals before the bar of justice, and as Francine Hirsch noted "conventional wisdom about the trials give little attention to the substantive role that the Soviets had in all aspects of the IMT." ${ }^{11}$ But it was the Soviet Union that immediately recognized the uniquely criminal aspects of the German war of annihilation and insistently called for such a tribunal. Many of the voluminous eyewitness protocols that were compiled by the Extraordinary Commission would be admitted as evidence without further corroboration both at the IMT and at other war crimes trials. The countless official military documents, reports and orders, as well as the interrogation records of captured German POW's and the official court records of war crimes trials held in the USSR prior to the Nuremberg trials were also accepted as evidence. ${ }^{62}$

The nature of Nazi warfare on the Eastern front had been criminal from the outset. The Soviets had been subjected to inhuman and barbaric acts which the regime went to great lengths to chronicle. The murder of millions of prisoners of war in violation of international law, the wholesale slaughter of Jews and the deaths of millions of other civilians from famine and deprivation during the occupation, the plundering of Soviet resources as well as the still untold story of the suffering of millions more Soviet citizens abducted for forced labor in Germany were all monstrous crimes. These were all meticulously documented by the Soviets in an enormous effort, which was in marked contrast to the efforts undertaken by the United Nations War Crimes Commission. According to Telford Taylor, the Chief US prosecutor at Nuremberg, the commission "had no investigatory staff or, for that matter, adequate staff for any substantial undertaking." ${ }^{63}$

National histories generally tend to highlight the positive contributions of their subjects and it should come as no surprise that American narratives emphasize the leading role played by the US in bringing the Nazis to account for their heinous crimes. But it was the Soviet leadership that had consistently called for an international criminal trial with the Nazi ringleaders in the dock for criminal conspiracy to commit aggressive war. As Hirsch correctly asserts "there is compelling evidence that the Soviet Union made significant contributions to the legal framework of the IMT."64 The legal principles posited by Aron Trainin were in fact adumbrations of those which would undergird the entire IMT framework. Although he ended his career as head of the Department of Criminal Law at Moscow State University and served as editor of one the most prestigious

\footnotetext{
${ }^{61}$ Hirsch, Soviets at Nuremberg, 702.

${ }^{62}$ For a complete discussion of the Soviet's impressive effort at the compilation of evidence see Marina Sorokina, "People and Procedures: Toward a History of the Investigation of Nazi Crimes in the USSR," Kritika: Explorations in Russian and Eurasian History 6, no. 4 (2005), 797-831.

${ }^{63}$ Taylor, Nuremberg Trials, 27.

${ }^{64}$ Hirsch, Soviets at Nuremberg, 703.
} 
Soviet legal journals, Sovetskoe Gosudarstvo i Pravo (Soviet State and Law), his contributions to the jurisprudence employed at the IMT were in fact downplayed even in Russia for a time as, according to one biographer, he "became a victim of the so-called 'struggle with cosmopolitanism." ${ }^{65}$ With Stalin's campaign against "rootless cosmopolitanism" in full swing, the Jewish Trainin was removed from his position as head of the Department of Criminal Law at Moscow State University, although this was "ostensibly due to his [poor] health." 66

He has since been the subject of well-deserved and laudatory biographical sketches in several Soviet and post-Soviet works. Not surprisingly, however, while Russian scholars and school children alike are made aware of the strenuous efforts made by the Soviet Union to see that justice was done for the victims of Nazi aggression, the important role played by Aron Trainin is less well known. In the West his seminal achievements were almost completely unnoticed until the works authored by Ginsburgs and Hirsch saw the light of day. The "master narrative" in the West posits that it was an American project to bring the Nazi leadership to justice. The most notable proponents of this viewpoint include Bradley Smith, who asserts that the "Nuremberg trial system was primarily developed in late 1944 and early 1945, almost exclusively by a group of American officials," and David Luban who avers that Nuremberg "was the brainchild of the Americans, who urged it upon their more or less unwilling allies." These asseverations have been proven demonstrably incorrect by both Hirsch and Kirsten Sellers. ${ }^{67}$

Of course, we cannot know for certain that Murray Bernays was wholly indebted to Trainin's idea; however, it was, in fact, the Soviets that had most consistently called for an international tribunal and they had also provided much of the necessary evidentiary documentation. And it was Aron Trainin who had elucidated the legal principles that would constitute the framework of the International Military Tribunal by calling for the prosecution of the entire top Nazi leadership as well as its financial and industrial minions for complicity in launching an aggressive, criminal war. But his important contributions to international jurisprudence did not stop there. Always an active and engaged participant in international legal conferences and other fora, he was heavily involved in the negotiations over the parameters of the legal definition of Genocide. Again, in the West the persistent and laudable campaign of Raphaël Lemkin (who, of course, coined the word genocide) to codify its definition and have its prohibition enshrined in international law is well known whereas Trainin's (and Vyshinskii's) important contributions towards these efforts are virtually ignored. The final product of the United Nations Convention on the Prevention and Punishment of the Crime of Genocide was in fact largely a compromise based on the strictures raised by these Soviet jurists.

In 1948, Trainin penned an article in the journal he edited, Sovetskoe gosudarstvo i pravo, entitled "Bor'ba s genotsidom kak mezhdunarodnym prestupleniem (The Struggle against Genocide as an International Crime). In this article he noted that it was indeed a unique kind of crime, different from any other, since it had as its aim the destruction of a whole group of people. Foreshadowing the definitional debates that have embroiled the field of Genocide Studies ever since its inception, Trainin differentiated between three forms of genocide. Physical genocide - the "direct physical extermination of people belonging to a certain race or nation;" Biological genocide - the "prevention of childbirth, sterilization, prohibition of marriage with the complete separation of sexes, forced abortions, etc.;" and "National and Cultural genocide aimed at destroying the national culture of persecuted peoples, its achievements and heritage." ${ }^{68}$ Another important post-war work was his Zaschita mira i bor'ba s prestupleniyami protiv chelovechestva (Defense of Peace and the Fight against Crimes against Humanity). ${ }^{69}$ Published in 1956, it reflected the culmination of a lifetime thinking about the role of law in ordering human society. Trainin believed that the idea of "crimes against mankind" included "the whole range of criminal acts which threaten the peace and security

\footnotetext{
${ }^{65}$ Bogush, A.N. Trainin, 173.

${ }^{66}$ Ibid.

${ }^{67}$ Smith, American Road, x; David Luban, “The Legacies of Nuremberg," Social Research, 54 (1987), 791.

${ }^{68}$ Aron N. Trainin, "Borba s genotsidom kak mezhdunarodnym prestupleniem," Sovetskoe gosudarstvo i pravo 5 (1948), 3.

${ }^{69}$ Aron N. Trainin, "Zashchita mira i bor'ba s prestupleniiami protiv chelovechestva," in Trainin, izbrannie proizvedeniia, ed. N. F. Kuznetsova (St. Petersburg: Iuridicheskii Center Press, 2004), 701.
} 
of nations. ${ }^{\prime 70}$ Regardless of the fact that he worked for one of the worst mass murderers in history, Trainin's life's work was in defense of peace and he helped to assure some measure of justice for the victims of the Nazi tyranny. Thus, Aron Trainin's contributions to international jurisprudence ought to be more widely known and recognized.

\section{Bibliography}

Arad, Yitzhak. The Holocaust in the Soviet Union. Lincoln and Jerusalem: University of Nebraska Press and Yad Vashem, 2009.

Ball, Howard. "The Path to Nuremberg: 1941-1945." In The Genocide Studies Reader, edited by Samuel Totten, 420-439. New York and London: Routledge, 2009.

Bogush, G. I. "A.N. Trainin i znachenie ego idei dlia niurnbergskogo protsessa." In Niurnbergskii protsess: uroki istorii, edited by N.S. Lebedeva and V.V. Ishchenko, 158-173. Moscow: Institut vseobshchei istorii RAN, 2007.

Ginsburgs, George. Moscow's Road to Nuremberg: The Soviet Background to the Trial. The Hague: Martinus Nijhoff, 1996.

Hirsch, Francine. "The Soviets at Nuremberg: International Law, Propaganda, and the Making of the Postwar Order." American Historical Review 113, no. 3 (2008), 701-730. https://doi.org/10.1086/ahr.113.3.701

Kochavi, Arieh, J. Prelude to Nuremberg: Allied War Crimes and the Question of Punishment. Chapel Hill: University of North Carolina Press, 2005.

Lebedeva, N. S. Podgotokva Niurnbergskogo protsessa. Moscow: Izdatel'stvo nauka, 1975.

---------, ed. SSSR i Nyurnbergskiy protsess. Neizvestnyye i maloizvestnyye stranitsy istorii. Moscow: MFD, 2012.

Marrus, Michael R. The Nuremberg War Crimes Trial, 1945-46: A Documentary History. Boston and New York: St. Martin's Press, 1997.

Minear, Richard. Victor's Justice: The Tokyo War Crimes Trial. Princeton: Princeton University Press, 1971.

Nota Narodnogo Komissara Inostrannykh Del Tov. V. M. Molotova O Chudovishchnykh Zlodeianiiakh Zverstvakh $i$ Nasiliiakh Germanskikh Vlastei v Okkypirovannykh Sovetskikh Raionakh i ob Otvetstvennosti Germanskikh Vlastei Za Eti Prestupleniia (People's Commissar of Foreign Affairs Comrade V. M. Molotov's Note Concerning the Monstrous Deeds, Atrocities and Acts of Violence of the German State in the Occupied Soviet Regions and About the Responsibility of the German State For These Crimes). April 27, 1942. United States Holocaust Memorial Museum, RG22.009.01.06.

Pikhoia, R.G. and V.P. Kozlov, eds. Katyn. Moscow: ROSSPEN, 1997.

Persico, Joseph. Nuremberg: Infamy on Trial. New York: Viking, 1994.

Rudenko, R. A. A.N. Trainin, Izbrannye Proizvedeneniia. Moscow: Gosizdat, 1969.

Sellars, Kirsten. Crimes Against Peace and International Law. Cambridge, UK: Cambridge University Press, 2013. https://doi.org/10.1017/CBO9781139236980

Smith, Bradley. The American Road to Nuremberg: The Documentary Record, 1944-1945. Stanford: Stanford University Press, 1982.

Snow, Edgar. The Pattern of Soviet Power. New York: Random House, 1945.

Soobshchenia Chrezvychainoi Gosudarstvennoi Kommissii po Ustanovleniiu i Rasledovaniiu Zlodeianii Nemetsko-Fashistikh Okkupantov i ikh posobnikov na Vremenno Okkupirovannoi Territorii SSSR. Moscow, 1944, tom 27.

Sorokina, Marina. "People and Procedures: Toward a History of the Investigation of Nazi Crimes in the USSR." Kritika: Explorations in Russian and Eurasian History 6, no. 4 (2005), 797-831. https://doi.org/10.1353/kri.2005.0060.

Soviet Government Statements on Nazi Atrocities. London: His Majesty's Lithography Office, 1946.

Stalin, Josef. War Speeches, Orders of the Day and Answers to Foreign Press Correspondents During the Great Patriotic War. London, n.d.

Taylor, Telford. The Anatomy of the Nuremberg Trials. New York: Alfred A. Knopf, 1992.

${ }^{70}$ Ibid. 
Trainin, Aron N. “Borba s genotsidom kak mezhdunarodnym prestupleniem." Sovetskoe gosudarstvo i pravo 5 (1948), 1-27.

-------. Ugolovnaia otvetsvennost' gitlerovtsev. Moscow: Iurid Izdatel'stvo NKIU Soiuza SSR, 1944.

--------. "Zashchita mira i bor'ba s prestupleniiami protiv chelovechestva." In Trainin, izbrannie proizvedeniia, edited by N. F. Kuznetsova, 667-722. St. Petersburg: Iuridicheskii Center Press, 2004.

United States Government. Foreign Relations of the United States: The Conference at Quebec, 1944. Washington, DC: Government Printing Office, 1972.

Vneshnaia politika Sovetskogo Soiuza v period otechestvennoi voiny. Moscow, 1946.

Weiss-Wendt, Anton. Casuistry of Blood: Genocide in the Political Discourse of the Cold War. Rutgers: Rutgers University Press, 2018.

. The Soviet Union and the Gutting of the Genocide Convention. Madison: University of Wisconsin Press, 2017. 